\title{
高分化型脂肪肉腫に対する手術治療の成績について
}

\author{
国立小倉病院整形外科 \\ 佐々木宏介・横山庫一郎 \\ 古 賀 正一郎・高比良 知 也 \\ 芳 賀 敏
}

\section{Surgical Treatment of Well-Differentiated Liposarcoma}

\author{
Kousuke Sasaki, Koichiro Yokoyama, Shoichirou Koga, \\ Tomonari Takahira, and Bin Haga \\ Department of Orthopaedic Surgery, \\ National Kokura Hospital
}

\begin{abstract}
Between 1976 and 1998, we experienced ten cases of well-differentiated liposarcomas. In all cases surgical treatment was performed. In the first operation, we performed marginal resection in eight cases, wide resection in one case, and intralesional resection in one case. Local recurrence appeared in three cases. Two cases underwent marginal resection and one case underwent intralesional resection.

The prognosis of well-differentiated liposarcomas is comparatively good. Metastasis does not appear except when they are dedifferentiated. Moreover, sometimes it is clinically difficult to distinguish them from some benign fatty soft tissue tumors. It should be better to preserve the nerves and vessels which are attached to the tumor and to resect the other tissues which are attached to the tumor with a wide margin as much as possible in the first operation.
\end{abstract}

Key words : Well-differentiated liposarcoma（高分化型脂肪肉腫）, Surgical treatment（手 術治療), Local recurrence (局所再発)

$$
\text { はじめに }
$$

高分化型脂肪肉腫は悪性軟部組織腫瘍としては発生 頻度が高く, 中高年者の大腿部, 鼠径部, 後腹膜に好 発する．肺などへの遠隔転移は非常に稀で予後良好な 疾患である．今回我々は, 高分化型脂肪肉腫に対する 手術治療成績について検討したので報告する.

\section{対象および方法}

1976 年から 1998 年までに手術した高分化型脂肪肉 腫 10 例である.男性 6 例，女性 4 例。年齢は 36 歳〜 71 歳 (平均 51.1 歳) であった。発生部位は大腿部が 9 例, 鼠径部が 1 例であった。腫瘍の大きさは $10 \times$
$10 \mathrm{~cm} \sim 15 \times 20 \mathrm{~cm}$ の範囲であった。組織学的には Lipoma-like liposarcoma が 6 例, Sclerosing type liposarcoma が 4 例であった。初回手術時よ りの追跡期間は, 2 力月 150 力月（平均 64.6 力月） であった（表 1$)$.

結

果

初回手術時の切除縁は, Marginal : 8 例, Intralesional : 1 例, Wide : 1 例であった。初回手術時 Marginal resectionを施行した 8 例中, 2 例に局所 再発を認めたが 6 例については現在まで局所再発は認 めず無病生存となっている。Wide resectionを施行 した 1 例は, 初回手術後 46 カ月で他病因にて死亡し 
表 1

\begin{tabular}{|c|c|c|c|c|c|c|}
\hline 症 例 & 発生部位 & 初回手術法 & 局所再発 & 最終手術法 & 最 終 予 後 & 組 織 型 \\
\hline $1: 46$ 歳 女 & 大腿部 & Marginal & 3 回 & Wide & 72 カ月（16 カ月） NED & Sclerosing \\
\hline $2: 57$ 歳 女 & 大腿部 & Marginal & 0 回 & & 96 カ月 & Sclerosing \\
\hline 3:42歳 男 & 大腿部 & Marginal & 0 回 & & 110 カ月 & Lipoma-like \\
\hline $4: 45$ 歳 女 & 大腿部 & Marginal & 2 回 & Marginal & 150 カ月（36 カ月） NED & Lipoma-like \\
\hline $5: 51$ 歳 男 & 大腿部 & Wide & 0 回 & & 46 力月 & Sclerosing \\
\hline $6: 63$ 歳 男 & 鼠径部 & Intralesional & 2 回 & Intralesional & 追跡不能 & Sclerosing \\
\hline $7: 71$ 歳 女 & 大腿部 & Marginal & 0 回 & & 84 カ月 & Lipoma-like \\
\hline $8: 36$ 歳 男 & 大腿部 & Marginal & 0 回 & & 54 カ月 & Lipoma-like \\
\hline $9: 37$ 墄 男 & 大腿部 & Marginal & 0 回 & & 2 力月 & Lipoma-like \\
\hline 10 : 63 歳 男 & 大腿部 & Marginal & 0 回 & & 2 カ月 & Lipoma-like \\
\hline
\end{tabular}

【注】（）内は，最終手術時よりの予後を表す．

たが局所再発は認めなかった. Intralesional resection となった 1 例は，鼠径部に発生したものである. 2 回局所再発し, 初回手術後 30 力月の時点で追跡不 能となった（表 1).

局所再発をきたした 3 例についてみると，切除縁は， Intralesional 1 例と Marginal 2 例であった. 組織 学的には Lipoma-like liposarcoma が 1 例， Sclerosing type liposarcoma が 2 例であった。 Intralesional resection となった 1 例は, 前述の如 く鼠径部に発生したものであり，媣部への浸潤が強く Marginal resection を施行することが困難であった ためである. 2 回局所再発し 2 回とも Intralesional resectionを施行した. Marginal resectionを施行 した 2 例中， 1 例は 2 回局所再発したが局所再発する 度に Marginal resectionを施行した. 最終手術後 36 カ月になる現在, 局所再発は認めず無病生存であ る. 他の 1 例は 3 回局所再発した. 1 回目, 2 回目の 局所再発時には Marginal resectionを施行したが 再度局所再発したため, 最終手術時にはWide resectionを施行した. その際血管も合併切除したため, 血行再建術も同時に施行した. 最終手術後 16 カ月に なる現在, 局所再発は認めず無病生存である（表 1 ).

\section{考察}

高分化型脂肪肉腫は, 年齢, 発生部位, 局在, MRI 所見, 生検にて診断される.ほとんどが中高年者の大 腿部, 鼠径部, 後腹膜に発生する。必ず筋膜より深部
の筋肉内に発生し，これは異型脂肪腫との鑑別上重要 である. MRI 所見としては，T1 強調画像にて腫瘍内 部は大部分が正常脂肪組織と同等の強い高信号を呈す るが, 一部に低信号の隔壁梯構造物を認める（図 1). $\mathrm{T} 2$ 強調画像にても，腫汮内部は大部分が正常脂肪組 織と等信号を呈し，一部に隔壁様構造物を認める（図 2). この隔壁様構造物は, $\mathrm{T} 1$ 強調画像では低信号に 描出されるが, T2 強調画像では低信号から高信号ま で様々な信号強度で描出される（図 2).MRIにて正 常脂肪組織と等信号に描出される部分は, 組織学的に 成熟脂肪細胞で占められる部分であり，隔壁様構造物 として描出される部分は, 組織学的に線維性組織から 成っている. 高分化型脂肪肉腫は, 組織学的に, 大部 分が成熟脂肪細胞で占められているが，内部の所々に 線維性隔壁を認める（図 3)。詳細に観察すると，多 数の空胞が集合した大きな核を有する異型性のある Lipoblast を認めることができる（図 4)。また，線 維性隔壁の周囲に異型細胞が多く集まっている傾向が 認められる. 生検にて Lipoblast が検出されれば確 定診断が得られる。しかしながら生検を施行しても確 定診断の得られない場合があり，その場合，脂肪腫， 異型脂肪腫, 筋肉内脂肪腫など他の良性脂肪性腫瘍と の鑑別が困難な場合がある．発生部位，局在，MRI 所見などから総合的に判断して治療計画を立てる必要 性がある。脱分化型以外は遠隔転移を生じることはな く生命予後は良好であるが，いわゆる摘出では再発す ることが多い. 初回手術後半年から 1 年で局所再発す 


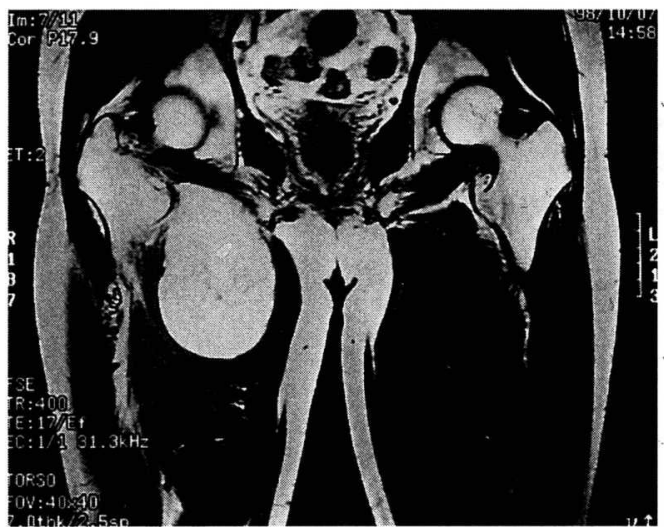

図 1 MRI T1 強調画像

腫瘍内部は大部分が正常脂肪組織と同じ強い高 信号を呈するが, 内部に低信号の隔壁様構造物 を認める。

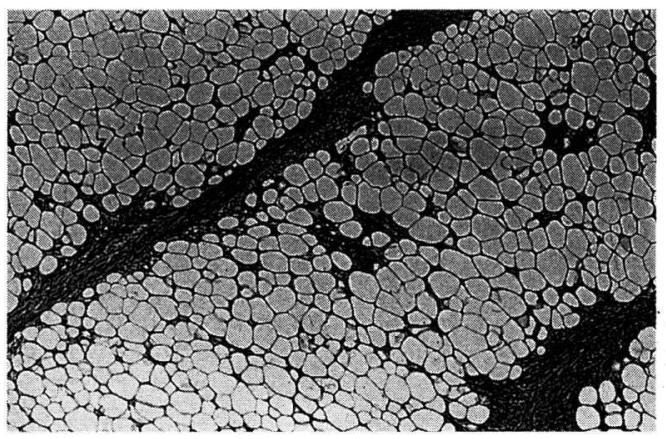

図 3 弱拡大組織像

大部分が成熟脂肪細胞で占められているが，内 部の所々に線維性隔壁を認める.

ることが多いが，10 年以上経過して局所再発するこ ともあり，長期間の Follow up が必要である.また， 局所再発を繰り返すうちに脱分化を生ずる可能性があ り，局所再発は出来る限り来さないようにすべきであ る.

一般に悪性軟部組織腫瘍に於いては，局所再発が 予後不良の大きな要因となるので，いわゆる広範切除 が施行されるが, 高分化型脂肪肉腫に限っては, Marginal resection が施行されることが多い. 初回 手術時 Marginal resection を施行した 8 例中 6 例 については局所再発を認めなかった。高分化型脂肪肉 腫に対する手術治療に拈いて我々は以下のように考え ている.

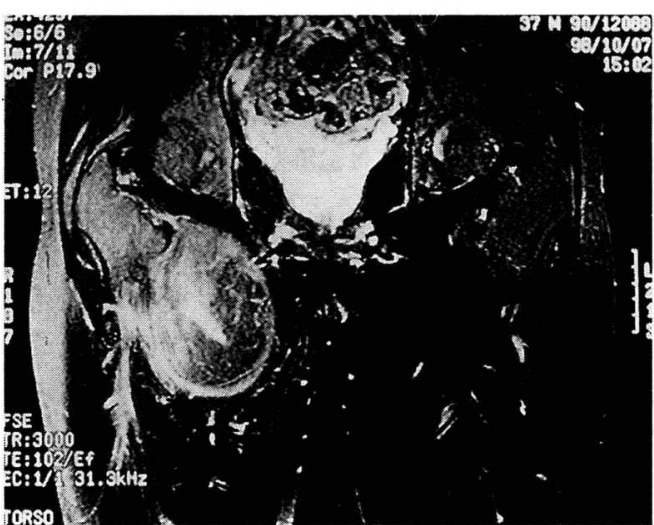

図 2 MRI T2 強調画像

腫瘍内部は大部分が正常脂肪組織と等信号を呈 するが, 内部に高信号の隔壁様構造物を認める.

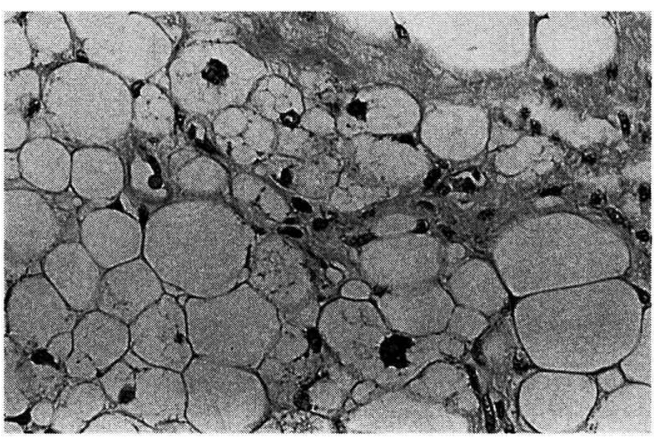

図 4 強拡大組織像

多数の空胞が集合した大きな核を有する異型性 のある Lipoblast を認める。

1:なるべくWide marginをめざすが, 部分的に Marginal margin になっても可と考える.

2 : 腫場辺縁は, 肉眼的に Lipoma 様で組織学的に 成熟脂肪細胞から成る部分と, 偽被膜が存在し組織学 的に線維性組織から成る部分が存在する. 線維性部分 に異型細胞が多く認められることから, 少なくとも線 維性の部分だけの Wide margin は確保すべきであ る.

3 : 辺縁部の線維性の部分で, 筋膜, 腱隆始部との癒 着が認められる.これらをWide marginにて切除 することで再発は防止できる可能性があると考える。 4 : 他の良性脂肪性腫瘍との鑑別が困難な場合があり， 生検を施行しても確定診断の得られない場合がある。 
従って少なくとも初回手術では, 神経および血管は温 存してみて良いのではないかと考える。

以上，高分化型脂肪肉腫の手術方針を考察したが， 今回の 10 症例に於いては追跡期間が短く, 10 年以上 経過して局所再発が生じることもあり, 今後も慎重に 経過観察していく必要性がある，また，我々の症例で は局所再発時に脱分化を生じた経験はないが，局所再 発時には常に脱分化を生じる危険性があることを念頭 において治療する必要性があり，手術時には，最小限 の健常組織を付ける努力はすべきであろう.

$$
\text { ま と め }
$$

(1)高分化型脂肪肉腫 10 例に対する手術治療成績を 検討した。

(2)局所再発は 10 例中 3 例に認められ，初回手術時 Marginal resectionを施行した 2 例と Intra- lesional resection を施行した 1 例であった。

(3)初回手術法としては, 腫瘍と癒着している神経お よび血管は温存するが，その他の腫瘍と瘉着している 組織については可及的にWide margin にて切除す るという方針でよいのではないかと考えられた.

\section{参 考 文 献}

1) Enzinger, F.M., Weiss, S. W.: Soft Tissue Tumors, Mosby, St. Louis, 2nd Ed., pp.346-382, 1988.

2) Jeline, J.S., Kransdort, M. J., Shmookler, B. M. et al.: Liposarcoma of the Extremities. Radiology, 186 : 455-459, 1993.

3）日本整形外科学会, 骨・軟部腫瘍編集委員会（編）: 骨·軟部腫瘍切除縁評価法（第 1版）, 金原出版, 東京, 1989.

4) 日本整形外科学会, 骨軟部腫瘍編集委員会編：整形外 科, 病理, 覀性軟部腫瘍取り扱い規約 (第 2 版), pp. 98104 . 金原出版, 東京, 1989 . 